\title{
Reduced ice number concentrations in contrails from low-aromatic biofuel blends
}

\author{
Tiziana Bräuer $^{1}$, Christiane Voigt ${ }^{1,2}$, Daniel Sauer ${ }^{1}$, Stefan Kaufmann $^{1}$, Valerian Hahn ${ }^{1}$, Monika Scheibe ${ }^{1}$, \\ Hans Schlager ${ }^{1}$, Felix Huber ${ }^{1,3}$, Patrick Le Clercq ${ }^{4}$, Richard H. Moore ${ }^{5}$, and Bruce E. Anderson ${ }^{5}$ \\ ${ }^{1}$ German Aerospace Center, Oberpfaffenhofen, Germany \\ ${ }^{2}$ Department of Physics, Mathematics, and Computer Science, Institute of Atmospheric Physics, Johannes Gutenberg \\ University Mainz, Mainz, Germany \\ ${ }^{3}$ Department of Aerospace Engineering, Institute of Space Technology and Space Applications, University of the Federal \\ Armed Forces in Munich, Munich, Germany \\ ${ }^{4}$ Institute of Combustion Technology, German Aerospace Center, Stuttgart, Germany \\ ${ }^{5}$ NASA Langley Research Center, Hampton, Virginia, USA
}

Correspondence: Tiziana Bräuer (tiziana.braeuer@dlr.de)

Received: 9 July 2021 - Discussion started: 27 July 2021

Revised: 11 October 2021 - Accepted: 14 October 2021 - Published: 19 November 2021

\begin{abstract}
Sustainable aviation fuels can reduce contrail ice numbers and radiative forcing by contrail cirrus. We measured apparent ice emission indices for fuels with varying aromatic content at altitude ranges of 9.1-9.8 and $11.4-11.6 \mathrm{~km}$. Measurement data were collected during the ECLIF II/NDMAX flight experiment in January 2018. The fuels varied in both aromatic quantity and type. Between a sustainable aviation fuel blend and a reference fuel Jet A1 , a maximum reduction in apparent ice emission indices of $40 \%$ was found. We show vertical ice number and extinction distributions for three different fuels and calculate representative contrail optical depths. Optical depths of contrails (0.5-3 min in age) were reduced by $40 \%$ to $52 \%$ for a sustainable aviation fuel compared to the reference fuel. Our measurements suggest that sustainable aviation fuels result in reduced ice particle numbers, extinction coefficients, optical depth and climate impact from contrails.
\end{abstract}

\section{Introduction}

In recent years, the scientific knowledge about climate forcing from global aviation emissions has constantly increased. Today, we know that air traffic contributes up to $4 \%$ to anthropogenic climate forcing (Lee et al., 2021). According to Lee et al. (2021) contrail cirrus was the biggest aviation climate forcer in 2018 with $57.4 \mathrm{~mW} \mathrm{~m}^{-2}$, followed by carbon dioxide emissions with $34.3 \mathrm{~mW} \mathrm{~m}^{-2}$ and nitrogen oxide emissions with $17.5 \mathrm{~mW} \mathrm{~m}^{-2}$. Besides new propulsion and fuselage concepts to reduce fuel consumption, the use of sustainable aviation fuels (SAFs) can be a solution to implement contrail mitigation. Similar to kerosene, SAFs consist of molecules containing mainly carbon and hydrogen. But in contrast to the crude-oil-based kerosene, SAFs are not dependent on fossilised carbon, and some have nearly zero aromatic content. The contrails studied in this paper formed by burning blends of hydrotreated esters and fatty acids (HEFA) and kerosene. HEFA is produced through transesterification and hydrogenation of bio-based oils (Kaltschmitt and Neuling, 2018). Due to the reduced aromatic content and varied hydrocarbon types in the fuels, they have the potential to change soot emissions and microphysical contrail properties (Voigt et al., 2021).

The number of initial contrail ice crystals is the driving factor for the development and the climate-relevant parameters of the contrails (Unterstrasser and Gierens, 2010; Burkhardt et al., 2018). Contrails are formed behind aircraft flying at altitudes above $8 \mathrm{~km}$ and in conditions typically colder than $-40^{\circ} \mathrm{C}$. The hot engine exhaust is mixed with ambient air, which cools the exhaust plume and increases the relative humidity with respect to liquid water (Kaufmann et al., 2014). If the conditions in the exhaust exceed water sat- 
uration, the non-volatile, ultra-fine soot particles emitted by the engines serve as condensation nuclei for water droplets. The droplets immediately freeze into ice particles (Heymsfield et al., 2010; Kärcher, 2018). The development of a lineshaped contrail is governed by the superposition of dynamic and microphysical processes, and the particle and trace gas concentrations are inhomogeneously distributed. A fraction of the ice crystals follow a downward movement and form the lower primary wake. At the same time the ice crystals in the upper part of the contrail, near the flight level, grow by uptake of water and form the secondary wake. Schumann et al. (2013) showed that the ice particle concentrations are larger in the secondary wake of the contrail. Vertical profiles of 1 to 4 min old contrails were also analysed by Gayet et al. (2012) and Jeßberger et al. (2013) with similar results. Kleine et al. (2018) assessed the sublimation effects with data of the ECLIF I experiment and showed that both soot and ice particle number concentrations are a function of the position behind and below the contrailing aircraft. An overview of contrail observations has been compiled by Schumann et al. (2017), and microphysical data on aged contrail cirrus have been analysed by Voigt et al. (2017) and Chauvigné et al. (2018).

The use of alternative jet fuels and their effect on soot emissions have been researched during ground and flight experiments before (Zschoke et al., 2012; Moore et al., 2015, 2017; Schripp et al., 2018; Tran et al., 2020). Moore et al. (2017) for example used in situ data to show that biofuel blending reduces soot particle number and mass emissions by $50 \%$ to $70 \%$. A reduction in contrail ice particle numbers of similar magnitude was first reported by Voigt et al. (2021) for semisynthetic and biofuel blends observed during the ECLIF I and ECLIF II/NDMAX experiments for limited conditions near $10 \mathrm{~km}$ altitude.

As ambient conditions have a large impact on microphysical contrail properties (Bräuer et al., 2021), a more comprehensive overview of the contrail ice measurements during ECLIF II/NDMAX is needed to assess the impact of biofuel blends on aviation climate impact. With this publication, we extend the study by Voigt et al. (2021) to a larger altitude range between 9.1 and $9.8 \mathrm{~km}$, and we also add observations for higher altitudes between 11.4 and $11.6 \mathrm{~km}$. We also describe our results with respect to a different reference fuel than the one used by Voigt et al. (2021). In the following, we analyse medium values and vertical profiles of apparent ice emission indices formed from burning fuels of varying composition. Burkhardt et al. (2018) showed with a global simulation that the climate impact of contrails is non-linearly dependent on apparent ice emission indices. Therefore, we contribute to the assessment of the contrail climate impact by deriving optical parameters like the extinction coefficients and contrail optical depths in addition to apparent ice emission indices.

\section{Experiment and instrumentation}

\subsection{ECLIF II/NDMAX}

The ECLIF II/NDMAX flight experiment was part of the DLR project Emission and Climate Impact of Alternative $\mathrm{Fu}-$ els (ECLIF) and the NASA DLR Multidisciplinary Airborne Experiment (NDMAX). It aimed to quantify the impact of jet fuel aromatic content and molecular structure on soot emissions, ice crystal formation and contrail properties (Bräuer et al., 2021; Voigt et al., 2021). The experiment took place in January 2018 over northern Germany. As emissions source aircraft, the DLR A320 Advanced Technology Research Aircraft with two V2527-A5 engines was used. The aircraft is shown in Fig. 1. The NASA DC-8 Airborne Science Laboratory followed the A320 at a distance between 4 and $30 \mathrm{~km}$ (far field) and measured non-volatile particle number and mass, ice crystal number size distributions, carbon dioxide $\left(\mathrm{CO}_{2}\right)$, and other emissions (Yang-Martin, 2021). The distances correspond to a contrail age between $30 \mathrm{~s}$ and $3 \mathrm{~min}$. These distances are necessary to avoid saturation of the optical particle counters. The aircraft followed each other on an elongated, oval flight track at altitudes between 7.8 and $11.6 \mathrm{~km}$. Distributions of the temperature and the relative humidity with respect to ice over the altitude are shown in Fig. 1.

During the ECLIF II/NDMAX airborne measurements, three different jet fuels were studied: a reference fuel Jet A-1 (Ref 3) and two blends of reference fuels and HEFA fuels produced from camelina oil (SAF 1 and SAF 2). Relevant fuel properties are described in Table 1. By varying blending ratios, different aromatic contents were obtained in the fuels. Aromatics are cyclic hydrocarbons, characterised by conjugated double bonds. Incomplete combustion of hydrocarbons in the fuels leads to the generation of soot particles. One type of aromatics, the stable, bicyclic naphthalene molecules, are thought to increase the sooting behaviour during fuel combustion (Chin and Lefebvre, 1990; Brem et al., 2015). Therefore, SAF 1 and SAF 2 are designed to vary in their naphthalene content, while their total aromatic content is in the same range. Results of the ground measurements during ECLIF II/NDMAX are published by Schripp et al. (2021).

\subsection{Particle and trace gas measurements}

Ice number concentrations were measured with the fast forward scattering spectrometer probe (FFSSP) in a particle size range between 1 and $25 \mu \mathrm{m}$ (Baumgardner and Gandrud, 1998). The instrument was mounted next to the $\mathrm{CO}_{2}$ inlet on the upper side of the DC- 8 fuselage. The probe has been previously used for contrail measurements (Voigt et al., 2010, 2011; Gayet et al., 2012; Chauvigné et al., 2018), and its electronics received an update in 2017, such that the recording of single-particle data is possible. The sampling 

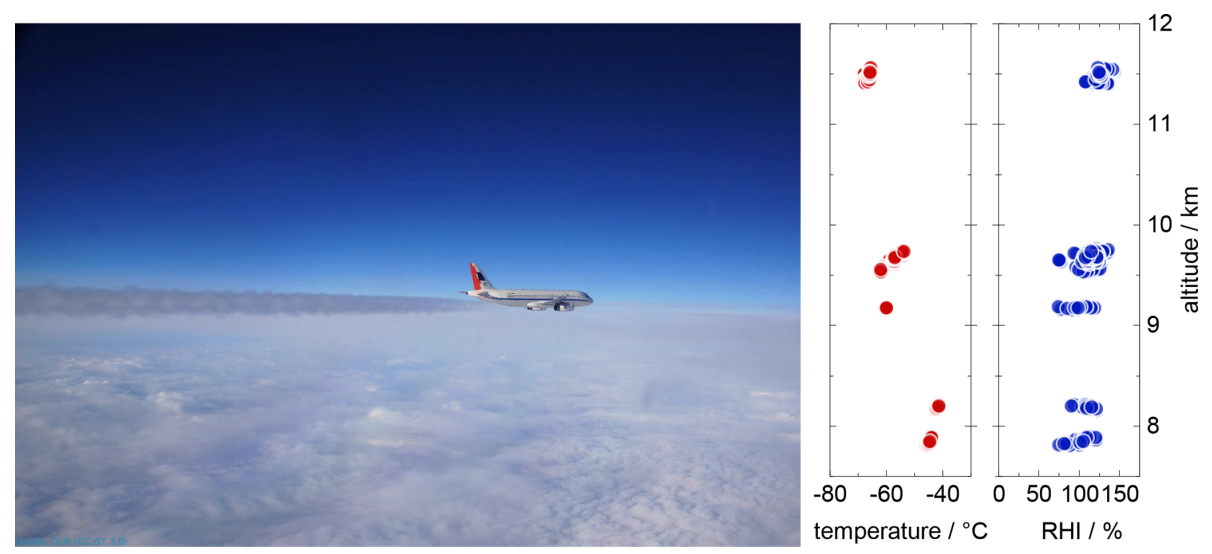

Figure 1. The DLR A320 with contrail in January 2018 during the ECLIF II/NDMAX flight experiment. Source of photograph: DLR (CCBY 3.0 DE). The plots show plume encounter mean values of the temperature and the relative humidity with respect to ice (RHI) versus altitude adapted from Bräuer et al. (2021).

Table 1. Properties and sample statistic of jet fuels burned during ECLIF II/NDMAX.

\begin{tabular}{|c|c|c|c|c|c|}
\hline & & $\begin{array}{r}\text { Sustainable } \\
\text { aviation } \\
\text { fuel } 1\end{array}$ & $\begin{array}{r}\text { Sustainable } \\
\text { aviation } \\
\text { fuel } 2\end{array}$ & $\begin{array}{r}\text { Reference } \\
\text { fuel } 3\end{array}$ & $\begin{array}{r}\text { Reference } \\
\text { fuel } 4^{\mathrm{e}}\end{array}$ \\
\hline Fuel composition & & $\begin{array}{r}51 \% \text { Ref } 3+ \\
49 \% \text { HEFA }\end{array}$ & $\begin{array}{r}70 \% \text { Ref } 4+ \\
30 \% \text { HEFA }\end{array}$ & $100 \%$ Jet A-1 & $100 \%$ Jet A-1 \\
\hline Aromatics $^{\mathrm{a}}$ & vol\% & 8.5 & 9.5 & 18.6 & 16.5 \\
\hline Naphthalene $\mathrm{b}^{\mathrm{b}}$ & mass $\%$ & 0.61 & 0.045 & 1.17 & 0.13 \\
\hline Hydrogen $^{c}$ & mass $\%$ & 14.40 & 14.51 & 13.65 & 14.08 \\
\hline $\mathrm{H}: \mathrm{C}$ ratio & & 2.005 & 2.023 & 1.884 & 1.953 \\
\hline Sulfur ${ }^{d}$ & mass $\%$ & 0.007 & $<0.001$ & 0.012 & $<0.001$ \\
\hline \multicolumn{6}{|l|}{ Contrail samples: } \\
\hline $9.1-9.8 \mathrm{~km}$ & & 103 & 63 & - & - \\
\hline $11.4-11.6 \mathrm{~km}$ & & 38 & 54 & 12 & - \\
\hline
\end{tabular}

${ }^{\mathrm{a}}$ ASTM D1319. ${ }^{\mathrm{b}}$ ASTM D1840. ${ }^{\mathrm{c}}$ ASTM D7171. ${ }^{\mathrm{d}}$ ISO 20884. ${ }^{\mathrm{e}}$ Only used during ground tests.

area of $0.19 \mathrm{~mm}^{2}$ was determined by laboratory calibrations, and the instrument was size-calibrated on the basis of a $\mathrm{T}$ matrix calculation for an ice particle aspect ratio of 0.5 (Borrmann et al., 2000; Luo et al., 2003; Rosenberg et al., 2012). The FFSSP particle size distributions were corrected for small particles, following Bräuer et al. (2021), so that particle concentration between 0.5 and $1 \mu \mathrm{m}$ can also be estimated. The correction is based on the Cloud and Aerosol Spectrometer (CAS), which was also part of the ECLIF II/NDMAX instrumentation and measures ice particles with diameters between 0.5 and $50 \mu \mathrm{m}$. A function was fitted to the ratio between the total CAS number concentration and the CAS number concentration for particles larger than $1 \mu \mathrm{m}$. The correction function increases exponentially with decreasing contrail effective diameter (Francis et al., 1994). The FFSSP ice number concentrations are corrected by multiplying them with the size-dependent correction function. The error of the correction increases with decreasing effective diameter (Bräuer et al., 2021).

$\mathrm{CO}_{2}$ was measured with a commercial Picarro G1301-m greenhouse gas analyser based on wavelength-scanned cavity ring-down spectroscopy (Crosson, 2008). Air from outside the aircraft was sampled by a backward facing inlet. Several calibrations were performed with commercial gas standards. The accuracy depends on the cell pressure of the instrument and its temperature during operation. Data are corrected for water vapour content following Rella et al. (2013). The time delay of the gas flow on the way from the inlet to the measurement cell was estimated to be $3.3 \mathrm{~s}$.

\section{Calculation of hydrogen-to-carbon ratio, emission index and extinction coefficient}

Kerosene contains mainly carbon, hydrogen and sulfur. It can be assumed that the sulfur content is negligible (in general 
less than 0.07 mass \%), and therefore the hydrogen-to-carbon $(\mathrm{H}: \mathrm{C})$ mole fraction ratio can be calculated for the known mass fraction of hydrogen $w_{\mathrm{H}}$ as follows:

$\frac{x_{\mathrm{H}}}{x_{\mathrm{C}}}=\frac{\frac{w_{\mathrm{H}}}{M_{\mathrm{H}}}}{\frac{100 \text { mass } \%-w_{\mathrm{H}}}{M_{\mathrm{C}}}}$.

Environmental conditions, instabilities in the trailing vortices and dilution lead to spatial inhomogeneities in the exhaust (Unterstrasser, 2016; Schumann and Heymsfield, 2017). Therefore, ice particle concentrations in an aircraft plume are normalised by $\mathrm{CO}_{2}$ as a proxy for fuel burn in order to calculate apparent emission indices (AEIs). The ice number concentrations are related to the mass of fuel burnt by scaling the measurements to the fuel-dependent $\mathrm{CO}_{2}$ emission index. For this calculation, we assume that the combustion system has $100 \%$ fuel conversion efficiency. As ice particles are not directly emitted by the engines, the term apparent ice particle emission index is used. Emission indices are calculated following Moore et al. (2017).

The individual impact of a contrail on radiation through the atmosphere depends on the extinction properties of the ice crystals. The extinction coefficient $b_{\text {ext }}$ depends on the extinction efficiency $Q_{\text {ext }}$, the projected area of the ice particles and the ice number concentration $N_{\text {ice }}$ (Schumann et al., 2011):

$b_{\mathrm{ext}}=\sum_{i} Q_{\mathrm{ext}} \cdot \pi\left(\frac{D_{i}}{2}\right)^{2} \cdot N_{\mathrm{ice}}$.

The extinction efficiencies were calculated for an aspect ratio of 1.0 and a wavelength of $550 \mathrm{~nm}$ and approach a value of 2 for large ice particles.

\section{Results and discussion}

\subsection{Fuel-dependent apparent ice emission indices}

As shown in Bräuer et al. (2021), temperatures near the contrail formation threshold temperature prevail when contrails are formed at altitudes below $9 \mathrm{~km}$, leading to an incomplete activation of soot particles into water (Kärcher and Voigt, 2017). At these low altitudes, even small temperature variations under $1 \mathrm{~K}$ significantly change the particle activation fraction and the ice number concentrations in the contrails. Therefore, we concentrate our study on altitudes above $9 \mathrm{~km}$. Voigt et al. (2021) showed a subset of the data at 9.1 to $9.8 \mathrm{~km}$ altitude, restricted to fuel flows of $1100 \pm 100 \mathrm{~kg} \mathrm{~h}^{-1}$ and relative humidity with respect to ice larger than $108 \%$. Here, we use the complete data set for the fuel intercomparison and discuss the resulting impact and limitations.

To present ice crystal number in contrails independent of contrail age and dilution, we calculate apparent ice emission indices (AEIs). In Fig. 2, AEIs are compared on the basis of the hydrogen-to-carbon $(\mathrm{H}: \mathrm{C})$ ratio of the varying fuels.

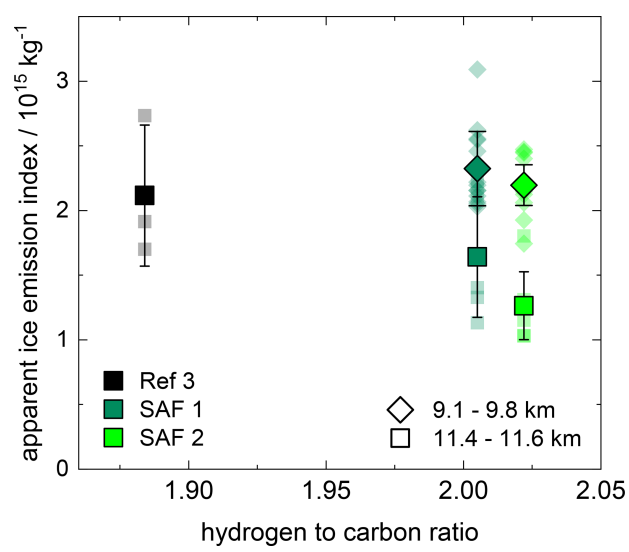

Figure 2. AEI with respect to the hydrogen-to-carbon $(\mathrm{H}: \mathrm{C})$ ratio of the fuels at two different flight altitudes. $\mathrm{H}: \mathrm{C}$ ratio of Ref 3 (black): 1.884; SAF 1 (dark green): 2.005; SAF 2 (light green): 2.022. Small symbols show the upper $15 \%$ of the single-plume encounters. Error bars show the standard deviations of the singleplume encounters.

For the contrails measured during ECLIF II/NDMAX (age between $30 \mathrm{~s}$ and $3 \mathrm{~min}$ ), sublimation effects can affect the ice numbers in the vortex phase and have to be excluded to receive a climate-relevant value for AEI. Therefore, we follow Bräuer et al. (2021) and calculate the mean of the upper $15 \%$ AEI. To ensure only contrails with full soot activation are considered, relative humidity with respect to ice is restricted to larger than $100 \%$ for altitudes between 9.1 and $9.8 \mathrm{~km}$ and larger than $120 \%$ for altitudes between 11.4 and $11.6 \mathrm{~km}$.

For high altitudes, we report a $23 \%$ reduction of AEI when burning SAF 1 compared to Ref 3 and a reduction of $40 \%$ when burning SAF 2. For altitudes between 9.1 and $9.8 \mathrm{~km}$, a $6 \%$ reduction is achieved when burning SAF 2 compared to $\mathrm{SAF} 1$. These values are in general agreement with previous observations. Voigt et al. (2021) found AEI reductions in the range of $50 \%$ to $70 \%$, when comparing to a different Jet A-1 reference fuel with lower hydrogen content. It can be stated that the number of ice crystals is reduced through the reduction of fuel aromatic content, which is also monitored by an increase in fuel hydrogen content. Changes in fuel polycyclic aromatic composition can further increase the reductions.

\subsection{Vertical profiles of contrail properties}

Figure 3 shows the vertical profiles of AEI ( $a$ and $b$ ) and the extinction coefficients ( $c$ and $d$ ) for the contrails resulting from burning each of the assessed fuels. The flight altitude of the A320 is the reference level and corresponds to $0 \mathrm{~m}$ vertical displacement on the $y$ axes of the figures. For reasons of simplicity, the mean values of several plume encounters are calculated in $30 \mathrm{~m}$ altitude sections. Because of the reduced number of plume encounters for the reference fuel Ref 3, sections with a depth of $60 \mathrm{~m}$ are calculated for this fuel. Only 
a selection of section-based standard deviations are shown to increase the clarity and readability of the plots. Due to unfavourable weather conditions, no contrails resulting from burning Ref 3 were observed at flight altitudes between 9.1 and $9.8 \mathrm{~km}$. The number of plume encounters per altitude and fuel type can be found in Table 1 .

The vertical profiles of AEI in Fig. 3a and b show typical distributions for the aircraft type A320 (Jeßberger et al., 2013; Schumann et al., 2013; Kleine et al., 2018). The measurements are distributed over a vertical range of $60 \mathrm{~m}$ above and up to $240 \mathrm{~m}$ beneath the reference level of the aircraft. The physical depth of a contrail varies with ambient conditions such as atmospheric stability and the humidity distribution. Produced by the same aircraft and at the same flight altitude in similar conditions, the physical depth is constant for varying fuels, even though in theory, different particle sizes lead to variations in sedimentation and sublimation processes (Unterstrasser and Görsch, 2014; Kleine et al., 2018).

Sublimation effects, which lead to a decrease in the ice crystal numbers in vertical direction below the A320, depend on the relative humidity over ice, temperature and atmospheric stability. Figure 4 shows two image recordings of the DC-8 forward camera during ECLIF II/NDMAX. Figure 4a shows a contrail unaffected by sublimation, and Fig. $4 \mathrm{~b}$ shows a contrail strongly affected by sublimation with a secondary wake forming above the descending contrail vortices. In Fig. 3a and b, sublimation effects of different emphasis can be observed in the vertical profiles of AEI. For both altitudes, AEIs are increased at the level of the secondary wake near the initial emission level at $0 \mathrm{~m}$. For altitudes between 9.1 and $9.8 \mathrm{~km}$, AEIs are also slightly increased in the lower primary wake, and sublimation effects are reduced at these altitudes. However, the highest AEIs are always found in the upper secondary wake as also shown by Kleine et al. (2018). Mean values of AEI are depicted by dashed, vertical lines, and in contrast to mean AEI in Fig. 2, these values consider all sublimation effects. At altitudes between 9.1 and $9.8 \mathrm{~km}$ the mean AEI is $1.3 \times 10^{15} \mathrm{~kg}^{-1}$ for SAF 1 and $7.4 \times 10^{14}$ $\mathrm{kg}^{-1}$ for SAF 2. The mean AEI at altitudes between 11.4 and $11.6 \mathrm{~km}$ is $5.9 \times 10^{14} \mathrm{~kg}^{-1}$ for SAF $1,5.8 \times 10^{14} \mathrm{~kg}^{-1}$ for SAF 2 and $1.2 \times 10^{15} \mathrm{~kg}^{-1}$ for Ref 3 .

The global climate impact of contrails is non-linearly dependent on the reduction of initial ice crystal numbers (Burkhardt et al., 2018). The dependence of contrail microphysical and radiative properties on initial ice crystal numbers then remains over the contrail cirrus life cycle. We calculate the extinction coefficients of the contrails to present the relation between contrail ice crystals and radiation. Unterstrasser and Gierens (2010) show that extinction is a suitable variable for comparing similarly aged contrails. The contrail life cycle further depends on meteorological parameters like temperature and humidity, vertical wind shear, atmospheric stability, the depth of the supersaturated layer in which the contrails are formed and the radiation budget (Schumann and Heymsfield, 2017; Unterstrasser et al., 2017).
The vertical profiles of the extinction coefficients are shown in Fig. 3c and d. At altitudes between 9.1 and $9.8 \mathrm{~km}$ the mean extinction coefficients are $2.5 \mathrm{~km}^{-1}$ for SAF 1 and $1.5 \mathrm{~km}^{-1}$ for SAF 2 . The mean extinction coefficients at altitudes between 11.4 and $11.6 \mathrm{~km}$ are $0.4 \mathrm{~km}^{-1}$ for SAF 1 and $0.6 \mathrm{~km}^{-1}$ for SAF 2 . The mean Ref 3 extinction coefficient at the altitude between 11.4 and $11.6 \mathrm{~km}$ is $1.5 \mathrm{~km}^{-1}$ and hence a factor of 2.5 higher than the mean extinction coefficients of both biofuels at the same altitude. In the following section the extinction coefficients are used to calculate the fueldependent contrail optical depths.

\subsection{Fuel-dependent contrail optical depth}

The contrail optical depth (COD) is a dimensionless measure of the degradation that a beam of radiation directed straight downwards experiences when passing through a contrail (Wallace and Hobbs, 2006). It is derived by integrating the extinction with respect to the vertical physical contrail depth. The ECLIF II/NDMAX CODs for the measured fuels are calculated by integration of the extinction coefficients shown in Fig. 3c and d (shaded areas). The resulting CODs for the three fuels at two different altitudes are presented in Fig. 5. The bars show the COD range for the uncertainty in physical contrail depths and are estimated based on the distribution of the measurements over the vertical range of the contrails. Fewer plume encounters were made for the Ref 3 fuel, which results in large variability bars.

For high altitudes, a COD reduction of $40 \%$ to $52 \%$ can be calculated when comparing the biofuel blends to the reference fuel. Due to atmospheric variability, it is not possible to evaluate the tendencies of the contrail optical depth that result from the sustainable aviation fuels. SAF 2 with reduced naphthalene content produces reduced AEI compared to SAF 1. But when calculating the climate-relevant parameter of optical depth during this early contrail age, the differences are reduced or even reversed. The reason is that reduced particle numbers under similar contrail formation conditions will lead to larger particles, as there is more water vapour available for particle growth. The ice particle sizes are strongly influenced by atmospheric conditions in the further contrail evolution, and therefore, they are highly variable. The total contrail extinction (Unterstrasser and Gierens, 2010; Unterstrasser and Görsch, 2014) and the radiative forcing of contrail cirrus (Burkhardt et al., 2018) are strongly dependent on initial ice crystal numbers. The optical depth varies strongly during the life cycle of a contrail (Unterstrasser and Gierens, 2010; Vázquez-Navarro et al., 2015).

In Fig. 5, the calculated CODs are compared with in situ and satellite observations (dashed and dotted lines) and model-derived values (compact lines). Freudenthaler et al. (1995) detected contrail height and width with a groundbased scanning lidar. Results covered a COD range of 0.05 to 1 for contrail ages between 1 and $60 \mathrm{~min}$ (Schumann et al., 2017). Voigt et al. (2011) determined optical depths of up to 

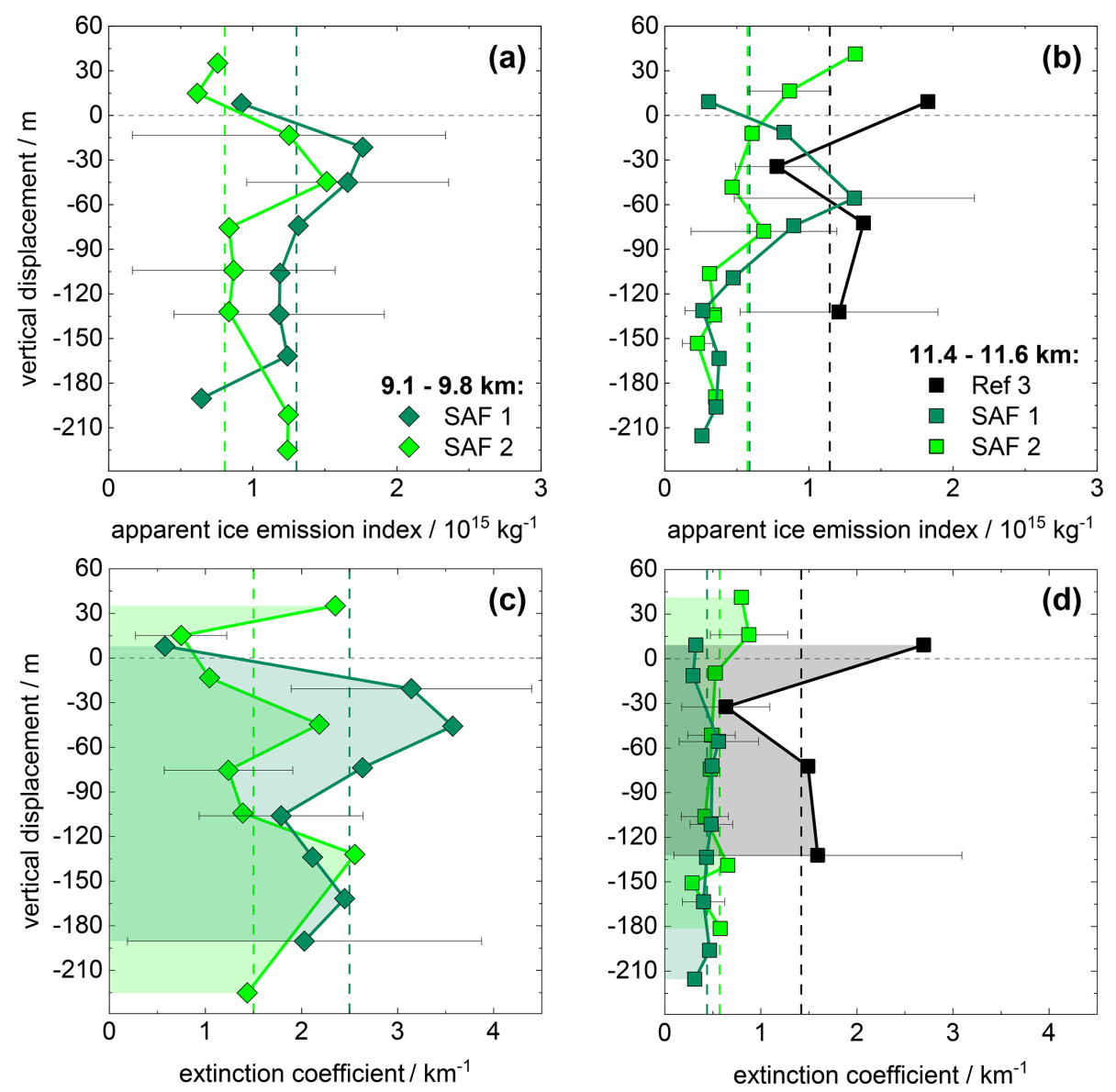

Figure 3. Profiles of mean AEI (a, b) and mean extinction coefficients (c, d) in $30 \mathrm{~m}$ sections (60 m for Ref 3). The A320 flight level is depicted by the grey horizontal reference line at $0 \mathrm{~m}$. Dashed vertical lines show overall means. Error bars show a selection of standard deviations of the single-plume encounters in $30 \mathrm{~m}$ sections $(60 \mathrm{~m}$ for Ref 3 ). The shaded areas in panels (c) and (d) show the calculation of the contrail optical depths by integration of the extinction coefficients. (a, c) $9.1-9.8 \mathrm{~km}$ (diamonds). (b, d) $11.4-11.6 \mathrm{~km}$ (squares).
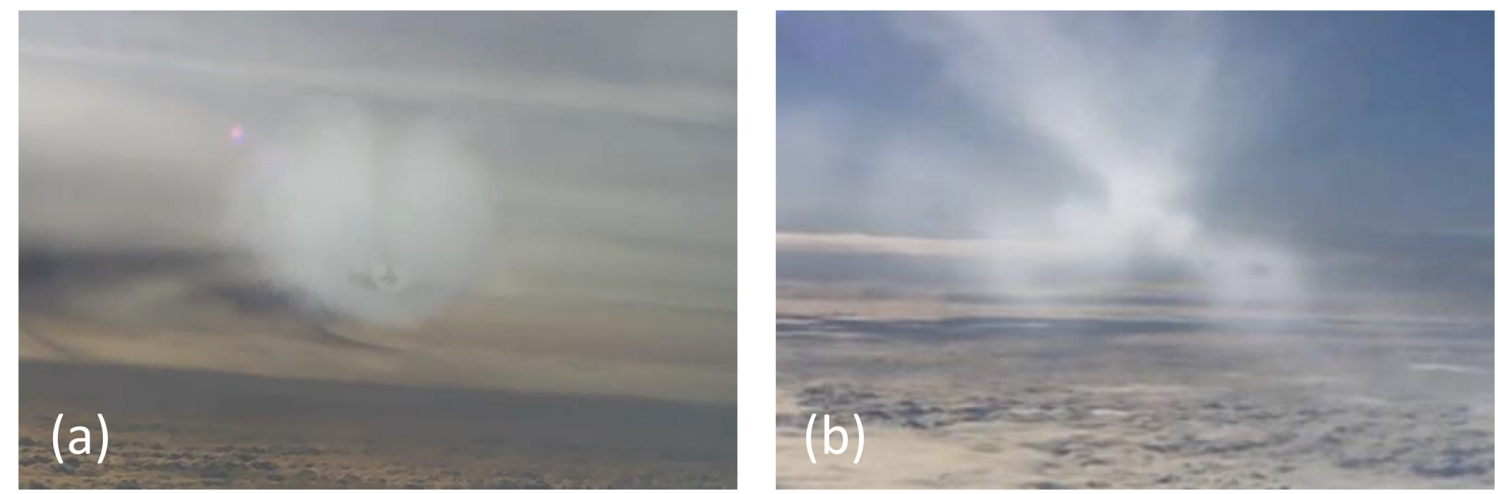

Figure 4. Contrails of the A320 recorded by the DC- 8 forward camera on two different days and for different ambient conditions during ECLIF II/NDMAX. Source: National Suborbital Research Center. (a) Contrail unaffected by sublimation. (b) Contrail affected by sublimation with a secondary wake forming above the descending contrail vortices. 


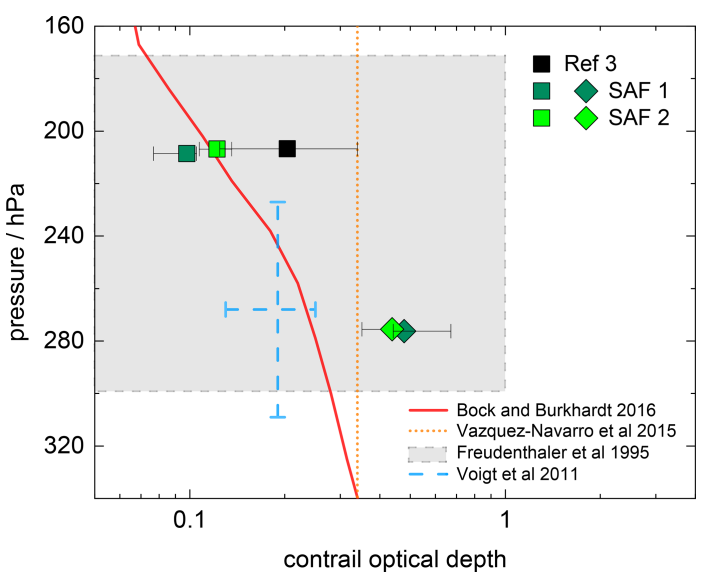

Figure 5. Individual contrail optical depths (CODs) determined from observations and models. Concerning the ECLIF II/NDMAX data, the fuels are distinguished by colour and the altitudes by symbol. Bars show the COD range for the uncertainty of the physical depths of the contrails.

6 min old contrails by in situ measurements. Data of the 2008 CONCERT experiment were used to derive the optical depth by multiplying the extinction with physical contrail depths calculated using dynamic vortex simulations by Holzäpfel (2006). Vázquez-Navarro et al. (2015) detected contrails with an automatic contrail tracking algorithm (ACTA) from Meteosat observations. The mean optical depth of contrails with an averaged lifetime of $1 \mathrm{~h}$ was 0.34 . Finally, Bock and Burkhardt (2016) used a contrail cirrus parameterisation developed for the ECHAM5 model to describe the mean optical depth of contrails in a vertical profile. Contrails were simulated to form between 30 and $70^{\circ} \mathrm{N}$ with optical depths greater than 0.05 and to have an age of $7.5 \mathrm{~min}$. Larger CODs at the lowest altitudes result from neglecting incomplete contrail activation near the contrail formation temperature and have been changed in subsequent studies (Burkhardt et al., 2018; Bock and Burkhardt, 2019). Figure 5 shows the variability and the range of contrail optical depths as a quantification of the individual contrail radiative impact. Varying averaging volumes and contrail ages lead to differences between COD derived from simulations and observations.

For contrail optical depths (CODs) smaller than 1, the contrail radiative forcing is proportional to COD (Meerkötter et al., 1999). Lee et al. (2021) give a consolidated estimate of contrail cirrus effective radiative forcing of $57.4 \mathrm{~mW} \mathrm{~m}^{-2}$. The estimations are based on several global climate models (Burkhardt and Kärcher, 2011; Chen and Gettelman, 2013; Schumann et al., 2015; Bock and Burkhardt, 2016; Bickel et al., 2020). A study by Gettelman et al. (2021) calculates a similar effective contrail radiative forcing of $62 \mathrm{~mW} \mathrm{~m}^{-2}$. Uncertainties for these values are high, inter alia, because the COD remains highly uncertain (Schumann et al., 2021a, b). Sanz-Morère et al. (2021) state that global estimations of average COD can vary from 0.065 to 0.3 . The individual CODs of ECLIF II/NDMAX are slightly higher than the underlying COD values of the current best effective radiative forcing estimate in Lee et al. (2021), which can be explained by the early development stage of the ECLIF II/NDMAX contrails.

\section{Conclusions and outlook}

For ECLIF II/NDMAX, up to $40 \%$ reduction in apparent ice emission indices was measured. SAF 1 and 2 had similar aromatic content but varied in aromatic type. An additional reduction in AEI of up to $20 \%$ was measured for the SAF with reduced naphthalene content. The individual contrail optical depth was reduced between $40 \%-52 \%$ for a sustainable aviation fuel compared to the reference fuel. For the future, a drastic reorientation of fuel compositions could provide strong benefits for climate, which comes without the cost of enhanced $\mathrm{CO}_{2}$ emissions when rerouting air traffic. Significant reduction of aviation climate forcing can be achieved by the widespread implementation of SAF blends in airport fuelling systems and by the use of unblended sustainable aviation fuels.

Data availability. The data are collected at the NASA data repository at https://science-data.larc.nasa.gov/aero-fp/projects/ (YangMartin, 2021).

Author contributions. CV, HS, PLC and BEA planned the flight experiment. PLC designed and organised the fuels. TB, CV, DS, SK, $\mathrm{VH}, \mathrm{MS}$, HS, FH, RHM and BEA performed the in-flight measurements, analysed the data and commented on the manuscript. TB performed the contrail ice data evaluation and wrote the paper. All authors contributed to the paper.

Competing interests. The contact author has declared that neither they nor their co-authors have any competing interests.

Disclaimer. Publisher's note: Copernicus Publications remains neutral with regard to jurisdictional claims in published maps and institutional affiliations.

Financial support. This research has been supported by the Helmholtz Association (grant no. W2/W3-60) and the Deutsche Forschungsgemeinschaft (grant nos. SSP HALO 1294 and VO 1504/7-1).

The article processing charges for this open-access publication were covered by the German Aerospace Center (DLR).

Review statement. This paper was edited by Allan Bertram and reviewed by Andrew Heymsfield and one anonymous referee. 


\section{References}

Baumgardner, D. and Gandrud, B. E.: A comparison of the microphysical and optical properties of particles in an aircraft contrail and mountain wave cloud, Geophys. Res. Lett., 25, 1129-1132, https://doi.org/10.1029/98GL00035, 1998.

Bickel, M., Ponater, M., Bock, L., Burkhardt, U., and Reineke, S.: Estimating the Effective Radiative Forcing of Contrail Cirrus, J. Climate, 33, 1991-2005, https://doi.org/10.1175/JCLI-D19-0467.1, 2020.

Bock, L. and Burkhardt, U.: Reassessing properties and radiative forcing of contrail cirrus using a climate model, J. Geophys. Res.-Atmos., 121, 9717-9736, https://doi.org/10.1002/2016JD025112, 2016.

Bock, L. and Burkhardt, U.: Contrail cirrus radiative forcing for future air traffic, Atmos. Chem. Phys., 19, 8163-8174, https://doi.org/10.5194/acp-19-8163-2019, 2019.

Borrmann, S., Luo, B., and Mishchenko, M.: Application of the TMatrix method to the measurement of aspherical (ellipsoidal) particles with forward scattering optical particle counters, J. Aerosol Sci., 31, 789-799, 2000.

Brem, B. T., Durdina, L., Siegerist, F., Beyerle, P., Bruderer, K., Rindlisbacher, T., Rocci-Denis, S., Andac, M. G., Zelina, J., Penanhoat, O., and Wang, J.: Effects of Fuel Aromatic Content on Nonvolatile Particulate Emissions of an In-Production Aircraft Gas Turbine, Environ. Sci. Technol., 49, 13149-13157, https://doi.org/10.1021/acs.est.5b04167, 2015.

Bräuer, T., Voigt, C., Sauer, D., Kaufmann, S., Hahn, V., Scheibe, M., Schlager, H., Diskin, G. S., Nowak, J. B., DiGangi, J. P., Huber, F., Moore, R. H., and Anderson, B. E.: Airborne Measurements of Contrail Ice Properties - Dependence on Temperature and Humidity, Geophys. Res. Lett., 48, e2020GL092166, https://doi.org/10.1029/2020GL092166, 2021.

Burkhardt, U. and Kärcher, B.: Global radiative forcing from contrail cirrus, Nat. Clim. Change, 1, 54-58, https://doi.org/10.1038/nclimate1068, 2011.

Burkhardt, U., Bock, L., and Bier, A.: Mitigating the contrail cirrus climate impact by reducing aircraft soot number emissions, NPJ Clim. Atmos. Sci., 1, 37, https://doi.org/10.1038/s41612018-0046-4, 2018.

Chauvigné, A., Jourdan, O., Schwarzenboeck, A., Gourbeyre, C., Gayet, J. F., Voigt, C., Schlager, H., Kaufmann, S., Borrmann, S., Molleker, S., Minikin, A., Jurkat, T., and Schumann, U.: Statistical analysis of contrail to cirrus evolution during the Contrail and Cirrus Experiment (CONCERT), Atmos. Chem. Phys., 18, 9803-9822, https://doi.org/10.5194/acp-18-9803-2018, 2018.

Chen, C.-C. and Gettelman, A.: Simulated radiative forcing from contrails and contrail cirrus, Atmos. Chem. Phys., 13, 1252512536, https://doi.org/10.5194/acp-13-12525-2013, 2013.

Chin, J. S. and Lefebvre, A. H.: Influence of Fuel Chemical Properties on Soot Emissions from Gas Turbine Combustors, Combust. Sci. Technol., 73, 479-486, https://doi.org/10.1080/00102209008951664, 1990.

Crosson, E. R.: A cavity ring-down analyzer for measuring atmospheric levels of methane, carbon dioxide, and water vapor, Appl. Phys. B, 92, 403-408, https://doi.org/10.1007/s00340-008-3135$\mathrm{y}, 2008$.

Francis, P. N., Jones, A., Saunders, R., Shine, K., Slingo, A., and Sun, Z.: An observational and theoretical study of the radiative properties of cirrus: Some results from ICE'89, Q. J. Roy. Meteor. Soc., 120, 809-848, https://doi.org/10.1002/qj.49712051804, 1994.

Freudenthaler, V., Homburg, F., and Jäger, H.: Contrail observations by ground-based scanning lidar: Crosssectional growth, Geophys. Res. Lett., 22, 3501-3504, https://doi.org/10.1029/95GL03549, 1995.

Gayet, J.-F., Shcherbakov, V., Voigt, C., Schumann, U., Schäuble, D., Jessberger, P., Petzold, A., Minikin, A., Schlager, H., Dubovik, O., and Lapyonok, T.: The evolution of microphysical and optical properties of an A380 contrail in the vortex phase, Atmos. Chem. Phys., 12, 6629-6643, https://doi.org/10.5194/acp12-6629-2012, 2012.

Gettelman, A., Chen, C.-C., and Bardeen, C. G.: The climate impact of COVID-19-induced contrail changes, Atmos. Chem. Phys., 21, 9405-9416, https://doi.org/10.5194/acp-219405-2021, 2021.

Heymsfield, A., Baumgardner, D., DeMott, P., Forster, P., Gierens, K., and Kärcher, B.: Contrail Microphysics, B. Am. Meteorol. Soc., 91, 465-472, https://doi.org/10.1175/2009BAMS2839.1, 2010.

Holzäpfel, F.: Probabilistic Two-Phase Aircraft Wake-Vortex Model: Further Development and Assessment, J. Aircraft, 43, 700-708, https://doi.org/10.2514/1.16798, 2006.

Jeßberger, P., Voigt, C., Schumann, U., Sölch, I., Schlager, H., Kaufmann, S., Petzold, A., Schäuble, D., and Gayet, J.-F.: Aircraft type influence on contrail properties, Atmos. Chem. Phys., 13, 11965-11984, https://doi.org/10.5194/acp-13-119652013, 2013.

Kaltschmitt, M. and Neuling, U. (Eds.): Biokerosene Status and Prospects, Springer, Berlin, Heidelberg, https://doi.org/10.1007/978-3-662-53065-8, 2018.

Kaufmann, S., Voigt, C., Jeßberger, P., Jurkat, T., Schlager, H., Schwarzenboeck, A., Klingebiel, M., and Thornberry, T.: In situ measurements of ice saturation in young contrails, Geophys. Res. Lett., 41, 702-709, https://doi.org/10.1002/2013GL058276, 2014.

Kleine, J., Voigt, C., Sauer, D., Schlager, H., Scheibe, M., Jurkat-Witschas, T., Kaufmann, S., Kärcher, B., and Anderson, B. E.: In Situ Observations of Ice Particle Losses in a Young Persistent Contrail, Geophys. Res. Lett., 45, 1355313561, https://doi.org/10.1029/2018GL079390, 2018.

Kärcher, B.: Formation and radiative forcing of contrail cirrus, Nat. Commun., 9, 1824, https://doi.org/10.1038/s41467-018-04068$0,2018$.

Kärcher, B. and Voigt, C.: Susceptibility of contrail ice crystal numbers to aircraft soot particle emissions, Geophys. Res. Lett., 44, 8037-8046, https://doi.org/10.1002/2017GL074949, 2017.

Lee, D., Fahey, D., Skowron, A., Allen, M., Burkhardt, U., Chen, Q., Doherty, S., Freeman, S., Forster, P., Fuglestvedt, J., Gettelman, A., De León, R., Lim, L., Lund, M., Millar, R., Owen, B., Penner, J., Pitari, G., Prather, M., Sausen, R., and Wilcox, L.: The contribution of global aviation to anthropogenic climate forcing for 2000 to 2018, Atmos. Environ., 244, 117834 , https://doi.org/10.1016/j.atmosenv.2020.117834, 2021.

Luo, B. P., Voigt, C., Fueglistaler, S., and Peter, T.: Extreme NAT supersaturations in mountain wave ice PSCs: A clue to NAT formation, J. Geophys. Res.-Atmos., 108, 4441, https://doi.org/10.1029/2002JD003104, 2003. 
Meerkötter, R., Schumann, U., Doelling, D. R., Minnis, P., Nakajima, T., and Tsushima, Y.: Radiative forcing by contrails, Ann. Geophys., 17, 1080-1094, https://doi.org/10.1007/s00585-9991080-7, 1999.

Moore, R. H., Shook, M., Beyersdorf, A., Corr, C., Herndon, S., Knighton, W. B., Miake-Lye, R., Thornhill, K. L., Winstead, E. L., Yu, Z., Ziemba, L. D., and Anderson, B. E.: Influence of Jet Fuel Composition on Aircraft Engine Emissions: A Synthesis of Aerosol Emissions Data from the NASA APEX, AAFEX, and ACCESS Missions, Energ. Fuel., 29, 2591-2600, https://doi.org/10.1021/ef502618w, 2015.

Moore, R. H., Thornhill, K. L., Weinzierl, B., Sauer, D., D’Ascoli, E., Kim, J., Lichtenstern, M., Scheibe, M., Beaton, B., Beyersdorf, A. J., Barrick, J., Bulzan, D., Corr, C. A., Crosbie, E., Jurkat, T., Martin, R., Riddick, D., Shook, M., Slover, G., Voigt, C., White, R., Winstead, E., Yasky, R., Ziemba, L. D., Brown, A., Schlager, H., and Anderson, B. E.: Biofuel blending reduces particle emissions from aircraft engines at cruise conditions, Nature, 543, 411-415, https://doi.org/10.1038/nature21420, 2017.

Rella, C. W., Chen, H., Andrews, A. E., Filges, A., Gerbig, C., Hatakka, J., Karion, A., Miles, N. L., Richardson, S. J., Steinbacher, M., Sweeney, C., Wastine, B., and Zellweger, C.: High accuracy measurements of dry mole fractions of carbon dioxide and methane in humid air, Atmos. Meas. Tech., 6, 837-860, https://doi.org/10.5194/amt-6-837-2013, 2013.

Rosenberg, P. D., Dean, A. R., Williams, P. I., Dorsey, J. R., Minikin, A., Pickering, M. A., and Petzold, A.: Particle sizing calibration with refractive index correction for light scattering optical particle counters and impacts upon PCASP and CDP data collected during the Fennec campaign, Atmos. Meas. Tech., 5, 1147-1163, https://doi.org/10.5194/amt-5-1147-2012, 2012.

Sanz-Morère, I., Eastham, S. D., Allroggen, F., Speth, R. L., and Barrett, S. R. H.: Impacts of multi-layer overlap on contrail radiative forcing, Atmos. Chem. Phys., 21, 1649-1681, https://doi.org/10.5194/acp-21-1649-2021, 2021.

Schripp, T., Anderson, B., Crosbie, E. C., Moore, R. H., Herrmann, F., Oßwald, P., Wahl, C., Kapernaum, M., Köhler, M., Le Clercq, P., Rauch, B., Eichler, P., Mikoviny, T., and Wisthaler, A.: Impact of Alternative Jet Fuels on Engine Exhaust Composition During the 2015 ECLIF Ground-Based Measurements Campaign, Environ. Sci. Technol., 52, 4969-4978, https://doi.org/10.1021/acs.est.7b06244, 2018.

Schripp, T., Anderson, B., LeClercq, P., Bauder, U., Corbin, J., Smallwood, G., Lobo, P., Crosbie, E. E., Shook, M., MiakeLye, R., Yu, Z., Freedman, A., Whitefield, P. D., Robinson, C. E., Achterberg, S. L., Köhler, M., Oßwald, P., Grein, T., Sauer, D., and Voigt, C.: Aircraft Engine Particulate Matter and Gaseous Emissions from Sustainable Aviation Fuels: Results from Ground-based Measurements during the NASA/DLR Campaign ECLIF2/ND-MAX, Elsevier Fuel, in preparation, 2021.

Schumann, U. and Heymsfield, A. J.: On the Life Cycle of Individual Contrails and Contrail Cirrus, Meteor. Mon., 58, 3.1-3.24, https://doi.org/10.1175/AMSMONOGRAPHS-D-160005.1, 2017.

Schumann, U., Mayer, B., Gierens, K., Unterstrasser, S., Jessberger, P., Petzold, A., Voigt, C., and Gayet, J.-F.: Effective Radius of Ice Particles in Cirrus and Contrails, J. Atmos. Sci., 68, 300-321, https://doi.org/10.1175/2010JAS3562.1, 2011.
Schumann, U., Jeßberger, P., and Voigt, C.: Contrail ice particles in aircraft wakes and their climatic importance, Geophys. Res. Lett., 40, 2867-2872, https://doi.org/10.1002/grl.50539, 2013.

Schumann, U., Penner, J. E., Chen, Y., Zhou, C., and Graf, K.: Dehydration effects from contrails in a coupled contrailclimate model, Atmos. Chem. Phys., 15, 11179-11199, https://doi.org/10.5194/acp-15-11179-2015, 2015.

Schumann, U., Baumann, R., Baumgardner, D., Bedka, S. T., Duda, D. P., Freudenthaler, V., Gayet, J.-F., Heymsfield, A. J., Minnis, P., Quante, M., Raschke, E., Schlager, H., Vázquez-Navarro, M., Voigt, C., and Wang, Z.: Properties of individual contrails: a compilation of observations and some comparisons, Atmos. Chem. Phys., 17, 403-438, https://doi.org/10.5194/acp-17-4032017, 2017.

Schumann, U., Bugliaro, L., Dörnbrack, A., Baumann, R., and Voigt, C.: Aviation Contrail Cirrus and Radiative Forcing Over Europe During 6 Months of COVID-19, Geophys. Res. Lett., 48, e2021GL092771, https://doi.org/10.1029/2021GL092771, 2021a.

Schumann, U., Poll, I., Teoh, R., Koelle, R., Spinielli, E., Molloy, J., Koudis, G. S., Baumann, R., Bugliaro, L., Stettler, M., and Voigt, C.: Air traffic and contrail changes over Europe during COVID-19: a model study, Atmos. Chem. Phys., 21, 7429-7450, https://doi.org/10.5194/acp-21-7429-2021, 2021 b.

Tran, S., Brown, A., and Olfert, J. S.: Comparison of Particle Number Emissions from In-Flight Aircraft Fueled with Jet A1, JP-5 and an Alcohol-to-Jet Fuel Blend, Energ. Fuel., 34, 7218-7222, https://doi.org/10.1021/acs.energyfuels.0c00260, 2020.

Unterstrasser, S.: Properties of young contrails - a parametrisation based on large-eddy simulations, Atmos. Chem. Phys., 16, 20592082, https://doi.org/10.5194/acp-16-2059-2016, 2016.

Unterstrasser, S. and Gierens, K.: Numerical simulations of contrail-to-cirrus transition - Part 2: Impact of initial ice crystal number, radiation, stratification, secondary nucleation and layer depth, Atmos. Chem. Phys., 10, 2037-2051, https://doi.org/10.5194/acp-10-2037-2010, 2010.

Unterstrasser, S. and Görsch, N.: Aircraft-type dependency of contrail evolution, J. Geophys. Res.-Atmos., 119, 14015-14027, https://doi.org/10.1002/2014JD022642, 2014.

Unterstrasser, S., Gierens, K., Sölch, I., and Lainer, M.: Numerical simulations of homogeneously nucleated natural cirrus and contrail-cirrus. Part 1: How different are they?, Meteorol. Z., 26, 621-642, https://doi.org/10.1127/metz/2016/0777, 2017.

Vázquez-Navarro, M., Mannstein, H., and Kox, S.: Contrail life cycle and properties from 1 year of MSG/SEVIRI rapid-scan images, Atmos. Chem. Phys., 15, 8739-8749, https://doi.org/10.5194/acp-15-8739-2015, 2015.

Voigt, C., Schumann, U., Jurkat, T., Schäuble, D., Schlager, H., Petzold, A., Gayet, J.-F., Krämer, M., Schneider, J., Borrmann, S., Schmale, J., Jessberger, P., Hamburger, T., Lichtenstern, M., Scheibe, M., Gourbeyre, C., Meyer, J., Kübbeler, M., Frey, W., Kalesse, H., Butler, T., Lawrence, M. G., Holzäpfel, F., Arnold, F., Wendisch, M., Döpelheuer, A., Gottschaldt, K., Baumann, R., Zöger, M., Sölch, I., Rautenhaus, M., and Dörnbrack, A.: In-situ observations of young contrails - overview and selected results from the CONCERT campaign, Atmos. Chem. Phys., 10, 90399056, https://doi.org/10.5194/acp-10-9039-2010, 2010.

Voigt, C., Schumann, U., Jessberger, P., Jurkat, T., Petzold, A., Gayet, J.-F., Krämer, M., Thornberry, T., and Fahey, D. W.: Ex- 
tinction and optical depth of contrails, Geophys. Res. Lett., 38, L11806, https://doi.org/10.1029/2011GL047189, 2011.

Voigt, C., Schumann, U., Minikin, A., Abdelmonem, A., Afchine, A., Borrmann, S., Boettcher, M., Buchholz, B., Bugliaro, L., Costa, A., Curtius, J., Dollner, M., Dörnbrack, A., Dreiling, V., Ebert, V., Ehrlich, A., Fix, A., Forster, L., Frank, F., Fütterer, D., Giez, A., Graf, K., Grooß, J.-U., Groß, S., Heimerl, K., Heinold, B., Hüneke, T., Järvinen, E., Jurkat, T., Kaufmann, S., Kenntner, M., Klingebiel, M., Klimach, T., Kohl, R., Krämer, M., Krisna, T. C., Luebke, A., Mayer, B., Mertes, S., Molleker, S., Petzold, A., Pfeilsticker, K., Port, M., Rapp, M., Reutter, P., Rolf, C., Rose, D., Sauer, D., Schäfler, A., Schlage, R., Schnaiter, M., Schneider, J., Spelten, N., Spichtinger, P., Stock, P., Walser, A., Weigel, R., Weinzierl, B., Wendisch, M., Werner, F., Wernli, H., Wirth, M., Zahn, A., Ziereis, H., and Zöger, M.: ML-CIRRUS: The Airborne Experiment on Natural Cirrus and Contrail Cirrus with the High-Altitude Long-Range Research Aircraft HALO, B. Am. Meteorol. Soc., 98, 271-288, https://doi.org/10.1175/BAMS-D15-00213.1, 2017.

Voigt, C., Kleine, J., Sauer, D., Moore, R. H., Bräuer, T., Clercq, P. L., Kaufmann, S., Scheibe, M., Jurkat-Witschas, T., Aigner, M., Bauder, U., Borrmann, S., Boose, Y., Crosbie, E., Diskin, G. S., DiGangi, J., Hahn, V., Huber, F., Nowak, J. B., Rauch, B., Rapp, M., Robinson, C., Schripp, T., Shook, M., Winstead, E., Ziemba, L., Schlager, H., and Anderson, B. E.: Cleaner burning jet fuels reduce contrail cloudiness, Nature Commun. Earth Environ., 2, 114, https://doi.org/10.1038/s43247021-00174-y, 2021.
Wallace, J. M. and Hobbs, P. V.: Atmospheric Science, 2nd Edn., Elsevier, Amsterdam, 2006.

Yang-Martin, M.: Public Projects List: NDMAX, NASA Aeronautics Research Mission Directorate [data set], available at: https://science-data.larc.nasa.gov/aero-fp/projects/, last access: 15 November 2021

Zschoke, A., Scheuermann, S., and Ortner, J.: High Biofuel Blends in Aviation (HBBA), Tech. rep., Deutsch Lufthansa AG and Wehrwissenschaftliches Institut für Werk- und Betriebsstoffe, available at: https://ec.europa.eu/energy/sites/ener/ files/documents/final_report_for_publication.pdf (last access: 15 November 2021), 2012. 